University of New Mexico

UNM Digital Repository

Anthropology Faculty \& Staff Publications

Anthropology

12-1-1999

\title{
Population History and the Islamization of the Iberian Peninsula: Skeletal Evidence from the Lower Alentejo Portugal
}

James L. Boone

Garnett P. McMillan

Follow this and additional works at: https://digitalrepository.unm.edu/anth_fsp

\section{Recommended Citation}

Current Anthropology, Vol. 40, No. 5 (December 1999), pp. 719-726

This Article is brought to you for free and open access by the Anthropology at UNM Digital Repository. It has been accepted for inclusion in Anthropology Faculty \& Staff Publications by an authorized administrator of UNM Digital Repository. For more information, please contact disc@unm.edu. 
Population History and the Islamization of the Iberian Peninsula: Skeletal Evidence from the Lower Alentejo of Portugal

Author(s): Garnett P. McMillan and James L. Boone

Source: Current Anthropology, Vol. 40, No. 5 (December 1999), pp. 719-726

Published by: The University of Chicago Press on behalf of Wenner-Gren Foundation for Anthropological Research

Stable URL: http://www.jstor.org/stable/10.1086/300091

Accessed: 23/08/2011 10:33

Your use of the JSTOR archive indicates your acceptance of the Terms \& Conditions of Use, available at http://www.jstor.org/page/info/about/policies/terms.jsp

JSTOR is a not-for-profit service that helps scholars, researchers, and students discover, use, and build upon a wide range of content in a trusted digital archive. We use information technology and tools to increase productivity and facilitate new forms of scholarship. For more information about JSTOR, please contact support@jstor.org. 
dalenian prehistory. British Archaeological Reports International Series 390.

KELLY, R. I995. The foraging spectrum: Diversity in huntergatherer lifeways. Washington, D.C.: Smithsonian Institution Press.

KUHN, S., AND M. STINER. I998. The earliest Aurignacian of Riparo Mochi. CURRENT ANTHROPOlOGY 39:Si75-Si 89.

LARICK, R. I983. The circulation of Solutrean foliate point cherts: Residential mobility in the Périgord. Ph.D. diss., State University of New York at Binghamton, Binghamton, N.Y.

LAVILLE, H. I968. L'abri du Facteur à Tursac (Dordogne): Etude sédimentologique du remplissage. Gallia Préhistoire I I I I): I 33-45.

LAVille, H., AND A. Tuffreau. I984. "Les dépôts du grand abri de la Ferrassie: Stratigraphie, signification climatique et chronologie," in Le grand abri de la Ferrassie. Edited by H. Delporte, pp. 25-50. Paris: Institut de Paléontologie Humaine.

LAVILle, H., J-P. RIGAUD, AND J. SACKetT. I980. Rock shelters of the Périgord: Geological stratigraphy and archaeological succession. New York: Academic Press.

LEROI-GOURHAN, ARL. I968. L'abri du Facteur à Tursac (Dordogne): Analyse pollinique. Gallia Préhistoire I I(I):I23-32. M O R A L A A I984. Périgordien et Aurignacien en Haut-Agenais: Etude d'ensembles lithiques. Toulouse: Ecole des Hautes Etudes en Sciences Sociales.

PAQUEREAU， M-M. I984. "Etude palynologique du gisement de la Ferrassie (Dordogne)," in Le grand abri de la Ferrassie. Edited by H. Delporte, pp. 5I-59. Paris: Institut de Paléontologie Humaine.

PEYRONy, D. I934. La Ferrassie: Moustérien, Périgordien, Aurignacien. Préhistoire 3:I-92.

P I к - T A Y, A. I99I. Red deer hunting in the Upper Paleolithic of southwest France: A study in seasonality. British Archaeological Reports International Series 569.

$\rightarrow$ ROLLAND, N., AND H. DIBBLE. I990. A new synthesis of Middle Paleolithic variability. American Antiquity 5 5:480-99.

Sнотт, M. I989. "Technological organization in Great Lakes Paleoindian assemblages," in Eastern Paleoindian lithic resource use. Edited by C. Ellis and J. Lothrop, pp. 22 I-37. Boulder: Westview Press.

SIMEK, J., AND L. SNYDER. I988. "Changing assemblage diversity in Périgord archaeofaunas," in The Upper Pleistocene prehistory of western Eurasia. Edited by H. Dibble and A. Montet-White, pp. 32 I-32. Philadelphia: University Museum Press.

SPIESS, A. I979. Reindeer and caribou hunters: An archaeological study. New York: Academic Press.

WHIT E, R. I985. Upper Paleolithic land use in the Périgord: A topographic approach to subsistence and settlement. British Archaeological Reports International Series 253.

. I989. Husbandry and herd control in the Upper Paleolithic: A critical review of the evidence. CURRENT ANTHROPOLOGY 30:609-32.

_. I993. "Technological and social dimensions of 'Aurignacian-age' body ornaments across Europe," in Before Lascaux: The complex record of the early Upper Paleolithic. Edited by H. Knecht, A. Pike-Tay, and R. White, pp. 277-99. Boca Raton: CRC Press.

WIL S ON, J. I975. "The last glacial environment at the Abri Pataud: A possible comparison," in Excavation of the Abri Pataud, Les Eyzies (Dordogne). Edited by H. L. Movius Jr., pp. I75-86. Cambridge: Peabody Museum, Harvard University.

W INTERHALDER, B. I98I. "Optimal foraging strategies and hunter-gatherer research in anthropology: Theory and models," in Hunter-gatherer foraging strategies. Edited by B. Winterhalder and E. Smith, pp. I3-35. Chicago: University of Chicago Press.

\section{Population History and the Islamization of the Iberian Peninsula: Skeletal Evidence from the Lower Alentejo of Portugal ${ }^{1}$}

\author{
GARNETT P. MCMILLAN AND JAMES L. BOONE \\ Department of Anthropology, University of New \\ Mexico, Albuquerque, N.M. 87 I3I, U.S.A. \\ (gnet@unm.edu)/(jboone@unm.edu). I6 xII 98
}

Despite the wealth of documentary evidence regarding the development of Andalusian civilization in the Iberian Peninsula following the first Muslim invasions in A.D. 7II, considerable controversy surrounds the issue of how to interpret the political, cultural, and demographic impact of Islamization on what is now Spain and Portugal. That Islamic civilization had a profound impact on the culture and language of Iberia cannot be questioned. Much debate, however, centers around the issue of the demographic impact of immigrating North African Berber and Arab settlers into Al-Andalus. Was the rise of Andalusian civilization primarily a process of conquest, immigration, and demographic and cultural replacement, or did conversion and the adoption and assimilation of Islamic culture and language by indigenous Hispano-Romans play an important role as well?

During most of the late I9th and 2oth centuries, the Islamic period was considered by most Iberian historians as an ephemeral foreign occupation-a kind of "historical parenthesis" - without lasting cultural or demographic effects on the Hispano-Roman tradition (Guichard 1976:24, 27). Today this view persists in the ubiquitous portrayal of a Portuguese or Spanish "us" and an Islamic "them" in both the scholarly and the popular literature (e.g., Alves I987). The historian Claudio Sanchez Albornoz (I956), for example, proposed that a Hispanic cultural and racial core had its origins in pre-Roman times and had remained more or less intact through a series of alien imperial expansionist episodes that included the Romans, the Visigoths, and finally the Muslims (Glick I979:7; Guichard I976:27). This "traditionalist" view of continuity was essentially a biological one: a Hispanic racial substrate with its own distinctive psychology and modal character prevailed, absorbing or assimilating any alien characteristics (Barceló I993:7).

A more analytic version of the traditionalist view today proposes that the vast majority of the population

I. (C) 1999 by The Wenner-Gren Foundation for Anthropological Research. All rights reserved oo I I-3204/99/4005-0008\$1.00. Funding for the research presented here was provided by the National Science Foundation, the Wenner-Gren Foundation, the Fundação Luso-Americano para Desenvolvimento, and the University of New Mexico. Logistical support was provided by the Câmara Municipal de Mértola and Campo Arqueológico de Mértola. Special thanks to Cláudio Torres and Santiago Macias for their advice and support. We thank Edward Bedrick and Elizabeth Dinsmore for their comments on earlier drafts of this paper. 
during the Islamic period was of indigenous origin and that Muslims entered the peninsula slowly and in small numbers and were gradually assimilated; after a few generations, the Muslim invaders had married into and allied themselves with Hispano-Roman families and become "Hispanicized" (Guichard 1976:27). In this view, the everyday aspects of domestic life, including family structure and material culture, are conservative and show no significant alterations or temporal lapses (see, e.g., Torres I984).

At the far end of the traditionalist spectrum is the idea that infusion of Islamic and Arab culture into the peninsula was purely the result of independent adoption by an indigenous population. One of the most extreme proponents of this view, Ignacio Olagüe (I974), argued that the Muslim invasions as such had never occurred and the Iberian peoples had essentially adopted Islam voluntarily and independently in preference to the decadent Visigothic culture, weakened by centuries of drought and plague. It is only fair to point out that the scenario envisioned by Olagüe is not without historical precedent in the spread of Islam. Islamization in the Far East, particularly the Indonesian Archipelago, occurred virtually entirely through proselytism by Muslim merchants, and Indonesia is one of the most populous Muslim countries in the world. But in the final analysis, the evidence that the Arab/Berber invasions of Iberia were real is overwhelming (perhaps the most important eyewitness document is the Chronicle of 754 , written in Latin by a Christian native of Iberia [see Collins I989]).

The primary opponent of the Hispanic-continuity model is the ethnohistorian Pierre Guichard (I976), who argues that the Islamic period represents a basic rupture with previous social and political systems, one in which "Oriental" social structures replaced the preexisting Hispano-Roman "Occidental" ones. Guichard further argues that the number of in-migrating Arabs and particularly North African Berbers was quite large and that their segmentary lineage organization, with its emphasis on clan endogamy, facilitated the rapid growth and expansion of these groups once they arrived in the peninsula while at the same time discouraging intermarriage with indigenous peoples and effectively limiting the amount of cultural assimilation that could have taken place. Thus, over the two or three centuries following the first invasions, Arab and Berber Muslims became a demographic as well as a political and cultural majority in the peninsula.

Guichard's argument is problematical in several respects. Much of his evidence regarding the lack of importance of intermarriage between Christians and Muslims in creating a Hispanic culture comes from genealogical sources that pertain to a rather small Arab urban political elite, while his general conclusions regarding the overall importance of clan endogamy in the rural hinterlands are entirely based on analogy with essentially modern Berber and Bedouin ethnographic descriptions. In fact, Guichard's best evidence for extensive Berber settlement in the hinterlands is limited to the existence of numerous Berber place-names (e.g., the com- mon Iberian toponym which includes the prefix Beni- or Banu-, "descendants of" in Arabic) in some areas of the peninsula. While such place-names may in fact constitute evidence for Berber settlement (although this argument is not without its opponents [e.g., Rubiera de Epalza I 984], these toponyms do not themselves say anything directly about the degree of intermarriage with and cultural assimilation by indigenous populations that may have occurred after initial settlement.

A less direct line of evidence for Berber settlement comes from tribal registries such as the one included in the chronicle written by Ibn Hazm, a mid-I I th-century Arab historian (Collins I989:I39), which lists immigrating Arab and Berber clans and indicates where they settled (Guichard I969:I22; Taha I989). Yet this document was written down nearly 300 years after the initial settlement was supposed to have taken place. On this basis, Collins (I989:I39) calls into question the reliability of Ibn Hazm's documentation. The mid-I Ith century was a period of intense political conflict during which claims for land rights were often reinforced by claims to pure Arabic and Arabized-Berber descent; histories during this period may well have been constructed in order to subvert competing claims to land rights and legitimacy while reinforcing the significance of the historian's or his patron's own. Collins concludes: "There is a danger that the Arab historians perpetuated in the interests of the cultural requirements of their own society classifications that had lost the basis for their reality long in the past" (I989:I39).

Nor does Guichard tell us what happened to the several millions of people who were living in the peninsula at the time of the first invasions. Bulliet (I979), in fact, has argued that a great deal of the Islamization of Iberia can be explained in terms of conversion of indigenous Hispano-Romans. The fact is, there is very little evidence regarding the nature of population movements and interaction that was actually written down during the formative period of the Islamic occupation (i.e., A.D. 7II-950), particularly with regard to the rural areas where most people actually lived. Clearly, the answers to these kinds of questions are going to have to come from archaeological research (see especially Glick I 995 on this point). Furthermore, it seems likely that the process of Islamization varied widely from region to region and was contingent upon variable environmental, demographic, economic, and political conditions.

In this paper we focus on the process of Islamization in the Lower Alentejo of southern Portugal in the region of the town of Mértola (fig. I). The town is located at the highest navigable point on the Guadiana River, about $70 \mathrm{~km}$ inland from the Algarve coast. It has served as an inland seaport tied to the Mediterranean economy since the Iron Age and was the site of a palatine area and forum during the early Roman period. It continued in its role as a port through the Late Roman period. It fell under Muslim rule within a few years of the initial Muslim invasions. During the Islamic period, Mértola was a strongly fortified central place and even briefly served as the political center of an independent Islamic taifa state 


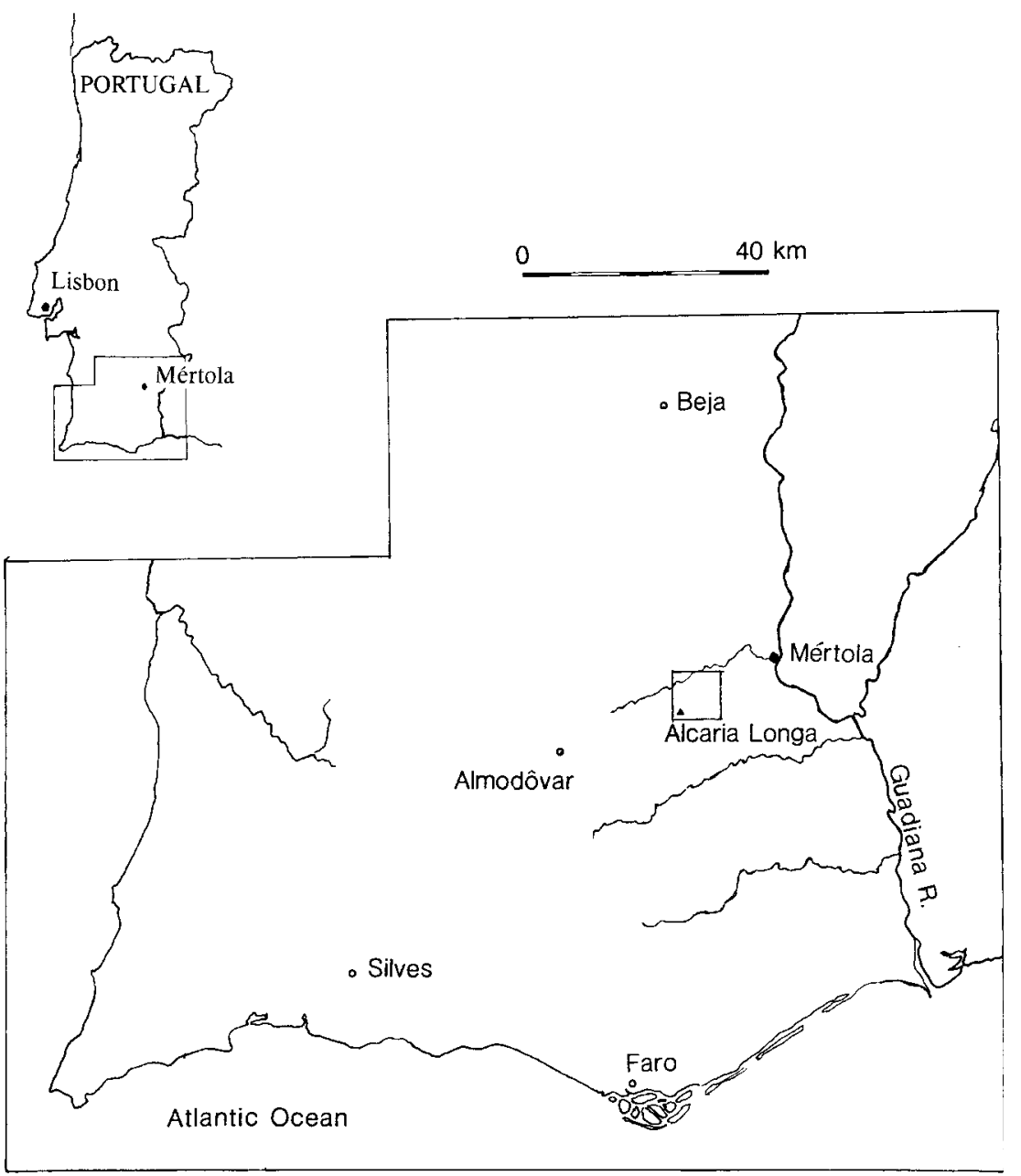

Fig. I. Map of the study area, showing Mértola, from which the skeletal series used in this study were drawn, and the survey area around Alcaria Longa, from which the site data were drawn.

during the mid-I2th century. It fell to Christian rule in A.D. I 238 .

Written sources indicate that the Guadiana River valley was the locus of dense Berber settlement during the early Islamic period, much of it concentrated in the northern reaches around Badajoz and Medellín (Taha I 989:I 27). In the Lower Alentejo there is some evidence that muwalladun-descendants of indigenous Christians converted to Islam-were politically important. For example, Ibn Qasi, the local leader of a Sufic revolt around A.D. I I 40 and briefly the leader of the Mértolan taifa state, was himself of muwalladun origin (Macias I993 $b: 427)$. Archeological research in the hinterlands of Mértola carried out by Boone (I992, I993, I994; Dinsmore I 994) has shown that the region experienced a rapid increase in population density during the Islamic period. In fact, the total settlement area increased almost eightfold from the Late Roman to the Islamic period (fig. 2). Much of our research in this area has been devoted to determining whether the increase in population was due to indigenous population growth or immigration by North African Berbers and Arabs.

In this paper, we compare a series of discrete (i.e., present/absent) genetically determined morphological traits of the cranium in two stratigraphically and temporally distinct skeletal populations recovered in the town of Mértola-one from the Late Roman/Paleo-Christian period (A.D. 450 to 7II), the other from the Islamic period (A.D. 7I I to I238)-to determine whether the two populations could have been drawn from the same gene pool.

\section{MATERIALS}

The two skeletal populations examined were excavated from a Paleo-Christian basilica located beneath a modern plaza, the Rossio do Carmo, and the adjoining primary school in the town of Mértola, District of Beja, Portugal (McMillan 1997). The excavations were conducted in I98 I-83 by a team from Campo Arqueológico de Mér- 


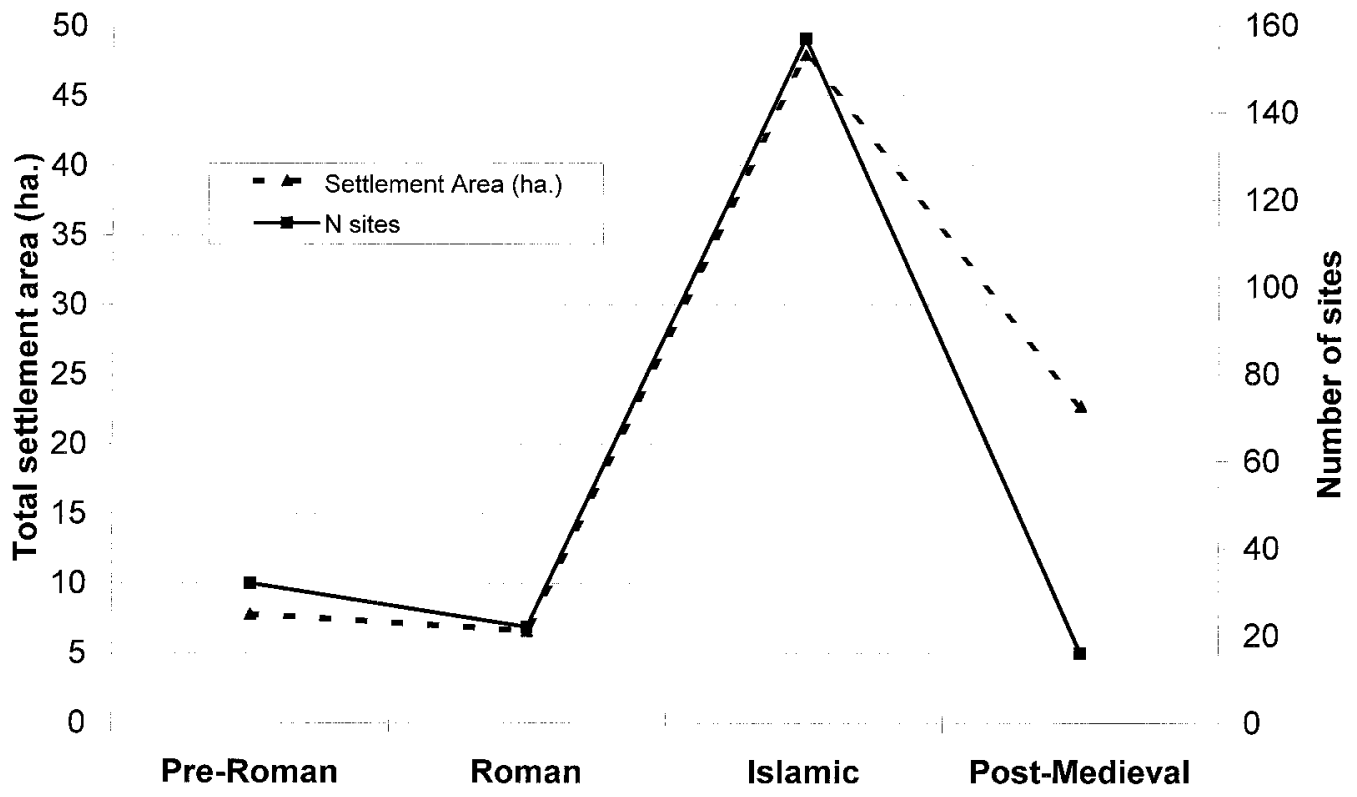

Fig. 2. Archaeological site frequencies and site sizes (in total hectares) over time for the survey area shown in figure $I$.

tola, an archeological research group based in Mértola with which Boone has collaborated since 1987.

The earliest group of interments is from beneath the floor of the basilica itself and from an area beneath a contemporary plaza surface just outside the building (the following description of the burials is based on Macias [1993a] and original fieldnotes archived at Campo Arqueológico de Mértola). These are clearly associated with the use of the basilica as a place of burial from the 5 th through the 7 th century A.D. Most of the tombs, which were often stone-and-plaster-lined cysts carved into the underlying bedrock, were covered with flat stone covers, 52 of which had legible inscriptions giving information regarding the name, age at death, date of death, and in some cases occupation or social class of the interred. Many of them contained more than one burial-evidence that the tombs were reused, perhaps to inter additional family members. Of the 40 tombstones which carried dates of death, $6(\mathrm{I} 5 \%)$ were from the late 5 th century, $24(60 \%)$ from A.D. 500-5 50, 7 (I $7.5 \%)$ from A.D. 550-600, and 2 from A.D. 6OI-700, and a single stone was dated A.D. 706. The majority of the tombstones record the burial of members of local landholding families or religious devotees (presbyters, monks, and nuns), many of whom were in all likelihood drawn from local families. A small proportion of the tombstones record the burial of foreigners-probably merchants and traders-from as far away as Libya.

The basilica apparently fell into disuse and collapsed or was torn down sometime after the Muslim invasion. The second group of interments was excavated from the rubble mound above the building itself and differed markedly from the first. Whereas the inhumations of the first group were all in supine position with heads oriented west-northwest, following the orientation of the structure and the direction of sunset, those of the second were all on their sides and slightly flexed, with heads oriented south and facing east, the direction of Mecca. No recognizable gravestones were associated with these burials, nor was there any special preparation of the graves themselves. The positioning of these burials is consistent with Islamic-period burials found elsewhere in the region and differs markedly from that of later, I4th- and I5th-century medieval Christian burials recovered from a nearby cemetery in the Alcaçova de Mértola, which were again supine and oriented toward the west. Hence, the inference that the rubble-mound burials date from the Islamic period (i.e., sometime between A.D. 7II and A.D. I248) seems secure.

\section{ANALYSIS}

We examined a total of I I I individuals, 57 from the Paleo-Christian series and 44 from the Islamic series, and recorded the presence or absence of 65 discrete morphological traits of the cranium (see table I) for each. (Five of these traits-bregmatic ossicles, right and left ossicles at asterion, and right and left parietal notches-were omitted from the analysis because no portions of the cranium in which these features are normally located were available for the Islamic series.) We then compared the proportional representation of these traits by applying a statistical measure of average difference between the two series in order to assess the degree of genetic difference between them. The null hypothesis to be 
Volume 40, Number 5, December 1999 | 723

TABLE I

Incidence, Sample Size, and Proportional Representation of 6o Cranial Traits Used in the Analysis

\begin{tabular}{|c|c|c|c|c|c|c|}
\hline \multirow[b]{2}{*}{ Trait } & \multicolumn{3}{|c|}{ Paleo-Christian } & \multicolumn{3}{|c|}{ Islamic } \\
\hline & Present & $N$ & Proportion & Present & $N$ & Proportion \\
\hline Coronal ossicle & I & 8 & O.I3 & I & I & I.OO \\
\hline \multicolumn{7}{|l|}{ Supra-orbital foramen, } \\
\hline \multicolumn{7}{|l|}{$\begin{array}{l}\text { Supra-orbital foramen, } \\
\text { complete }(1)\end{array}$} \\
\hline Frontal notch $(\mathrm{r})$ & $\mathrm{o}$ & I5 & 0.00 & o & 3 & 0.00 \\
\hline Frontal notch (1) & 4 & I6 & 0.25 & 0 & 2 & 0.00 \\
\hline Frontal foramen $(\mathrm{r})$ & 4 & I6 & 0.25 & I & 3 & 0.33 \\
\hline Frontal foramen (1) & 3 & I6 & 0.19 & o & 2 & 0.00 \\
\hline Zygomatic foramen $(\mathrm{r})$ & I2 & I3 & 0.92 & 2 & 2 & 1.00 \\
\hline Zygomatic foramen (1) & IO & I5 & 0.67 & I & 2 & 0.50 \\
\hline \multicolumn{7}{|l|}{ Accessory zygomatic } \\
\hline foramen $(\mathrm{r})$ & I & I I & 0.10 & 0 & 3 & 0.00 \\
\hline \multicolumn{7}{|l|}{ Accessory zygomatic } \\
\hline Os japonicum (r) & o & I 2 & 0.00 & o & 3 & 0.00 \\
\hline Os japonicum (1) & $\mathrm{o}$ & I4 & 0.00 & 0 & 3 & 0.00 \\
\hline Infra-orbital suture $(\mathrm{r})$ & 3 & I I & 0.27 & I & 3 & 0.33 \\
\hline Infra-orbital suture (1) & I & I4 & 0.07 & I & 3 & 0.33 \\
\hline \multicolumn{7}{|l|}{ Zygo-maxillary } \\
\hline tubercle $(\mathrm{r})$ & 2 & I 2 & 0.16 & I & 4 & 0.25 \\
\hline \multicolumn{7}{|l|}{ Zygo-maxillary } \\
\hline tubercle (1) & 3 & I4 & $0.2 \mathrm{I}$ & I & 3 & 0.33 \\
\hline Maxillary torus (r) & I & I3 & 0.08 & o & 3 & 0.00 \\
\hline Maxillary torus (1) & $\mathrm{o}$ & I4 & 0.00 & o & 4 & 0.00 \\
\hline Epiteric bone $(\mathrm{r})$ & $\mathrm{o}$ & 2 & 0.00 & o & I & 0.00 \\
\hline Epiteric bone (1) & $\mathrm{o}$ & 3 & 0.00 & o & I & 0.00 \\
\hline \multicolumn{7}{|l|}{ Fronto-temporal artic- } \\
\hline ulation $(\mathrm{r})$ & $\mathrm{o}$ & 4 & 0.00 & 0 & I & 0.00 \\
\hline \multicolumn{7}{|l|}{ Fronto-temporal artic- } \\
\hline ulation (1) & 0 & 6 & 0.00 & 0 & I & 0.00 \\
\hline Parietal foramen $(\mathrm{r})$ & 4 & I 3 & $0.3 \mathrm{I}$ & 2 & 2 & I.00 \\
\hline Parietal foramen (1) & 5 & I2 & 0.42 & I & 2 & 0.50 \\
\hline Sagittal ossicle & I & 7 & O.I4 & 0 & I & 0.00 \\
\hline Ossicle at lambda & I & IO & O.I I & 0 & 4 & 0.00 \\
\hline Os inca & 0 & 9 & 0.00 & 0 & 5 & 0.00 \\
\hline Lambdoid ossicle $(\mathrm{r})$ & I & 9 & O.II & 2 & 4 & 0.50 \\
\hline Lambdoid ossicle (1) & I & 8 & 0.13 & o & 2 & 0.00 \\
\hline \multicolumn{7}{|l|}{ Ossicle in mastoid } \\
\hline \multirow{2}{*}{\multicolumn{7}{|c|}{ Ossicle in mastoid }} \\
\hline & & & & & & \\
\hline suture (1) & I & 5 & 0.20 & I & 2 & 0.50 \\
\hline \multicolumn{7}{|l|}{ Petrosquamous } \\
\hline \multirow{2}{*}{\multicolumn{7}{|c|}{$\begin{array}{c}\text { suture }(\mathrm{r}) \\
\text { Petrosquamous }\end{array}$}} \\
\hline & & & & & & \\
\hline suture (1) & $\mathrm{o}$ & I I & 0.00 & I & 4 & 0.25 \\
\hline Mastoid foramen $(\mathrm{r})$ & 5 & IO & 0.50 & 2 & 2 & 1.00 \\
\hline Mastoid foramen (1) & I & 7 & O.I4 & 2 & 3 & 0.67 \\
\hline Mastoid foramen, & & & & & & \\
\hline extra-sutural (r) & 4 & 9 & 0.44 & $\mathrm{O}$ & 2 & 0.00 \\
\hline $\begin{array}{l}\text { Mastoid foramen, } \\
\text { extra-sutural (1) }\end{array}$ & 6 & 7 & 0.86 & I & 3 & 0.33 \\
\hline Palatine torus & o & I 5 & 0.00 & o & 3 & 0.00 \\
\hline Accessory lesser pala- & & & & & & \\
\hline tine foramen $(\mathrm{r})$ & 3 & I I & 0.27 & o & I & 0.00 \\
\hline Accessory lesser pala- & & & & & & \\
\hline tine foramen (1) & I & I 2 & 0.08 & o & I & 0.00 \\
\hline Pharyngeal fossa & 2 & I 2 & 0.17 & $\mathrm{o}$ & I & 0.00 \\
\hline Foramen ovale, & & & & & & \\
\hline complete $(\mathrm{r})$ & o & $\mathrm{I} 2$ & 0.00 & $\mathrm{o}$ & I & 0.00 \\
\hline Foramen ovale, & & & & & & \\
\hline complete $(1)$ & I & IO & 0.10 & 0 & I & 0.00 \\
\hline $\begin{array}{l}\text { Foramen spinosum, } \\
\text { open }(\mathrm{r})\end{array}$ & 4 & I3 & $0.3 \mathrm{I}$ & 0 & I & 0.00 \\
\hline
\end{tabular}


TABLE I (Continued)

\begin{tabular}{|c|c|c|c|c|c|c|}
\hline \multirow[b]{2}{*}{ Trait } & \multicolumn{3}{|c|}{ Paleo-Christian } & \multicolumn{3}{|c|}{ Islamic } \\
\hline & Present & $N$ & Proportion & Present & $N$ & Proportion \\
\hline \multicolumn{7}{|l|}{$\begin{array}{l}\text { Foramen spinosum, } \\
\text { open (1) }\end{array}$} \\
\hline Double condylar & & & & & & \\
\hline $\begin{array}{l}\text { facet }(\mathrm{r}) \\
\text { Double condylar }\end{array}$ & o & I 3 & 0.00 & I & I & I.OO \\
\hline $\begin{array}{l}\text { facet (1) } \\
\text { Posterior condylar }\end{array}$ & o & I I & 0.00 & $\mathrm{o}$ & I & 0.00 \\
\hline $\begin{array}{l}\text { canal }(\mathrm{r}) \\
\text { Posterior condylar }\end{array}$ & 4 & $\mathrm{I} 2$ & 0.33 & 0 & I I & 0.00 \\
\hline $\begin{array}{l}\text { canal (l) } \\
\text { Hypoglossal canal, }\end{array}$ & 3 & IO & 0.30 & $\mathrm{o}$ & I & 0.00 \\
\hline $\begin{array}{l}\text { double }(\mathrm{r}) \\
\text { Hypoglossal canal, }\end{array}$ & o & I I & 0.00 & $\mathrm{o}$ & I & 0.00 \\
\hline double (1) & $\mathrm{o}$ & IO & 0.00 & o & I & 0.00 \\
\hline Mandibular torus (r) & $\mathrm{o}$ & I 8 & 0.00 & o & 9 & 0.00 \\
\hline Mandibular torus (1) & $\mathrm{o}$ & I6 & 0.00 & $\mathrm{o}$ & 9 & 0.00 \\
\hline $\begin{array}{l}\text { Mental foramen, } \\
\text { double }(\mathrm{r})\end{array}$ & I & I9 & 0.05 & I & I 2 & 0.08 \\
\hline $\begin{array}{l}\text { Mental foramen, } \\
\text { double (1) } \\
\text { Accessory mandibular }\end{array}$ & I & I 8 & 0.06 & $\mathrm{o}$ & I I & 0.00 \\
\hline $\begin{array}{l}\text { Accessory mandibular } \\
\text { foramen }(\mathrm{r})\end{array}$ & I & I 8 & 0.06 & 0 & 7 & 0.00 \\
\hline $\begin{array}{l}\text { Accessory mandibular } \\
\text { foramen (1) }\end{array}$ & I & I4 & 0.07 & 0 & 6 & 0.00 \\
\hline Mylo-hyloid bridge (r) & 2 & $\begin{array}{l}14 \\
17\end{array}$ & O.I2 & $\mathrm{o}$ & 6 & 0.00 \\
\hline Mylo-hyloid bridge (1) & I & I 5 & 0.07 & o & 6 & 0.00 \\
\hline
\end{tabular}

tested here is that the Paleo-Christian and Islamic series were drawn from the same gene pool.

Discrete traits have been used to characterize gene pools of archaeological populations since the I960s (Berry and Berry 1967). Early analyses of genetic distance using this method assumed that presence or absence of a trait was determined entirely by genetic factors and that the mechanism of inheritance was relatively simple-that a single genetic locus determined the presence or absence of a trait. These assumptions have more recently been shown in numerous instances to be problematic (Green and Suchey I976, Hauser and DeStefano I989, Saunders 1989, Sjovold I973). It now appears that at least some discrete skeletal traits are expressed quasicontinuously because of environmental and multiple-locus interactions and that genetic predisposition determines a threshold the crossing of which during physiological development results in the trait's expression. For the purposes of this study, we made the simplifying and not unreasonable assumption that the two populations under analysis were subjected to similar environmental influences during development.

To assess whether the two series were different, we used a divergence measure modified from Berry (I963; Berry and Berry 1967) by Sjovold (1973) and Green and Suchey (I 976). This measure evaluates differences in proportional representation of an array of traits while stabilizing the variance of the differences in order to make them independent of the proportions. The two principal formulae used in the calculation of the degree of divergence are as follows:

$$
\text { Mean divergence }=\sum_{i=1}^{r} \frac{\left(\theta_{1 i}-\theta_{2 i}\right)^{2}-\left(\frac{1}{n_{1 i}+1 / 2}+\frac{1}{n_{2 i}+1 / 2}\right)}{r}
$$

and

Variance of mean divergence $=$

$$
\frac{2}{r^{2}} \sum_{i=1}^{r}\left(\frac{1}{n_{1 i}+1 / 2}+\frac{1}{n_{2 i}+1 / 2}\right)^{2},
$$

where $r=$ the number of discrete traits $i$ examined, $n_{k i}=$ sample size in population $k$ for trait $i$, and $\theta=A r c s i n-$ transformed proportion (Green and Suchey i 976:65).

A formal statistical test of the difference between populations is based on the fact that the mean divergence divided by the square root of the variance of mean divergence-hereafter referred to as the $D$ statistic-is distributed as standard normal (Green and Suchey I976). Thus, the $D$ statistic is read as a standard normal deviate and gives the probability that the difference between the two populations is equal to zero. This is equivalent to the probability that the two samples were drawn from the same gene pool. 


\section{RESULTS}

In this analysis we estimated the average divergence between the Paleo-Christian and Islamic series based on 64 discrete traits of the cranium. Following the method just described, $D$ was estimated to be -0.I 4 and its variance estimated as 0.0096 . This converts to a standard normal deviate of $-\mathrm{I} .434$, and the probability that there is no difference between the two populations is 0.076 . This is a somewhat marginal result, but there is good reason to think that it may be somewhat inflated.

Green and Suchey observe (I976) that variance estimates may be inflated for traits for which there are fewer than about 20 observations and that have small proportional representations. All the traits we examined had samples of fewer than 20, and proportions varied from $\mathrm{O}$ to I. In order to examine the possibility of the influence of inflated variance on the $D$ statistic, we compared the proportional representation with the sample size for each trait. The expectation was that if small proportions are associated with small sample sizes, then there should be a significant positive correlation between proportional presence and sample size. This in turn would suggest that the variance of $D$ is too large and the $p$ value (0.076) for the difference of $D$ from o is too conservative. When this possibility was tested by means of a Spearman's rank correlation of untransformed percent present on sample size for both skeletal series, the result was positive (Spearman's rho $=0.169)$ and fairly significant $(p<0.0645$; d.f. = I I 8). This indicates that inflated variance estimates due to small sample sizes may be important and that the actual $p$ value for the differences between the two populations is smaller than our estimated value of 0.076 . These results strongly suggest that it is unlikely that the Paleo-Christian and the Islamic populations were drawn from the same gene pool.

Two potential problems remain. First, the variance of mean divergence is influenced by sample size and the total number of traits examined. In this study the Islamic materials in particular are characterized by very small sample sizes (median $=2$ ), which has the effect of inflating the variance estimate. At the same time, the examination of 59 traits reduces the variance of mean divergence markedly. Second, the influence of intertrait correlation on the results was not examined. This is an empirical question that should be assessed for each pair of traits under consideration. Small sample sizes obviated the kinds of detailed analyses suggested by Green, Suchey, and Gokhale (I979). Sjovold (I977) argues that assessing intertrait correlation is problematic when the number of traits is large. Alpha error will produce at least some combinations which show significant intertrait correlation, leaving one without means of evaluating whether those traits should be omitted from the analysis.

\section{CONCLUSIONS}

The analysis of genetic divergence by means of discrete cranial traits indicates that the Paleo-Christian and Islamic skeletal series excavated from the Rossio do
Carmo basilica are unlikely to have been drawn from the same gene pool and that the burials are from two different populations. The question, then, is why they are different.

As we noted above, the Islamic period is characterized by a nearly eightfold increase in both site numbers and total settlement area, so it is tempting to suggest that the difference between the two burial populations is due to the influx of a new population into the area-perhaps Arabs or Berbers associated with the Muslim occupation. However, we emphasize that the increase is due to an increase in the number of small rural hamlets and villages in the hinterlands. Archaeologically, there is evidence for a considerable amount of material-culture continuity (e.g., in rooftile decoration, household spatial organization, ceramic manufacture methods and vessel forms) between the Paleo-Christian and Islamic periods (Boone I994, I996), suggesting that some of the increase in site numbers is due to intrinsic growth of an indigenous rural population. Therefore we should remain cautious about identifying it with the influx of a new population from outside. Analysis of skeletal series from village cemeteries would help to clarify this issue, but so far none have been excavated.

In contrast, it is reasonable to suggest that the two basilica burial series analyzed here are drawn from a privileged subpopulation of landowners, townspeople, and perhaps political leaders residing in the central place of Mértola itself. This population, then, may have been more subject to changes in composition due to sociopolitical factors. However, although we suggest that the high degree of divergence between the Paleo-Christian and the Islamic basilica series is due to the appearance of a foreign population in the Islamic period, this new population may have come from anywhere and was not necessarily Arab or Berber in origin. This issue could be clarified by comparing the Islamic-period series with skeletal populations of known Berber and Arab origin, preferably from the medieval period.

\section{References Cited}

ALves, A. I987. "Alguns aspectos de Alentejo árabe e sua incidência no perfil português," in II Congresso sobre o Alentejo: Semeando novos rumos, pp. 27-34. Beja: Edição da Associação de Municipios do Distrito de Beja.

B A R C ELó, M. I993. Per Quina arqueologia per al-Andalus? Arqueologia Medieval 2:5-16.

BERRY, R. J. I963. Epigenetic polymorphisms in wild populations of Mus musculus. Genetical Research 4:193-220.

BERRY, R. J., AND A. C. BERRY. I967. Epigenetic variation in the human cranium. Journal of Anatomy IOI:36I-79.

в OONE, J. L. I992. The first two seasons of excavations at Alcaria Longa. Arqueologia Medieval I:5 I-64.

. I993. The third season of excavations at Alcaria Longa. Arqueologia Medieval 2:I I I-25.

- I994. "Rural settlement and Islamization: The evidence from Alcaria Longa." Actas del Encuentro de Arqueologia del Suroeste. Mértola: Grupo de Investigación Arqueología del Suroeste no. 5272 del P.A.I., Campo Arqueológico de Mértola. - I996. Uma sociedade tribal no Baixo Alentejo medieval? Arqueologia Medieval 2: I I-25. 
B Ulliet, R. W. I979. Conversion to Islam in the Medieval period: An essay in quantitative history. Cambridge: Cambridge University Press.

COLLINS, R. I989. The Arab conquest of Spain: 710-797. Cambridge: Basil Blackwell.

DINSMORE, E. S. I994. "Rural settlement and political change: An intersite analysis of Roman and Islamic period settlement organization in the Baixo Alentejo, Portugal. Master's thesis, Department of Anthropology, Arizona State University, Tempe, Ariz.

GLICK, T. F. I979. Islamic and Christian Spain in the early Middle Ages. Princeton: Princeton University Press.

. I995. From Muslim fortress to Christian castle. Manchester: Manchester University Press.

$\rightarrow$ GREEN, R. F., AND J. M. SUCHEY. I976. The use of inverse sine transformations in the analysis of non-metric cranial data. American Journal of Physical Anthropology 45: $6 \mathrm{I}-68$.

$\rightarrow$ GReEN, R. E., J. M. SUCheY, AND D. V. GOKHAle I979. The statistical treatment of correlated bilateral traits in the analysis of cranial material. American Journal of Physical Anthropology 50:629-34.

GUICHARD, P. I969. Le peuplement de la region de Valence aux deux premiers siècles de la domination musulmane. Mélange de la Casa Velasquez 5:103-56.

- I976. Al-Andalus: Estructura antropologica de una sociedade islamica en Occidente. Barcelona: Barral Editores.

HAUSER, G., AND G. F. DESTEFANO. I989. Epigenetic variants of the human skull. Stuttgart: E. Schweizerbart'sche Verlagsbuchhandlung (Nagele U. Obermiller).

MACIAs, s. I993a. "Um espacio funerario," in Basilica Paleocristã. Edited by C. Torres and S. Macias, pp. 30-57. Mértola: Campo Arqueológico de Mértola.

I993b. "O Gharb al-Andalus: Resenha dos factos políticos," in História de Portugal, vol. I, Antes de Portugal. Edited by José Mattoso. Lisbon: Editorial Estampa.

MC MiLlAN, G. P. I997. A preliminary analysis of the PaleoChristian and Islamic cemeteries of Rossio do Carmo, Mértola, Portugal. Arqueologia Medieval 5:I 5-22.

OL A G̈̈ E, I. I974. La revolución Islamica en Occidente. Barcelona: Fundación Juan March.

RUBiERA DE EPALZA， M. J. I984. "Toponimia aràbigo-valenciana: Falsos antropónimos beréberes," in Estudis en memória del professor Manuel Sanchis Guarner: Estudis de llengua i literatura catalanes. Valéncia: Universitat de Valéncia.

SANCHEZ AL B ORNOZ, C. I956. España: Un enigma histórico. 2 vols. Buenos Aires: Editorial Sudamericana.

SA U N DERS, S. R. I989. "Nonmetric skeletal variation," in Reconstruction of life from the skeleton. Edited by I. M. Iscan and K. Kennedy, pp. 95-I08. New York: Alan R. Liss.

SJOVOLD, T. I973. The occurrence of minor, non-metrical variants in the skeleton and their quantitative treatment for population comparisons. Homo 24:204-33.

- I977. Non-metrical divergence between skeletal populations. Ossa 4(suppl. I):I-I33.

T A A A. W. D. I989. The Muslim conquest and settlement of North Africa and Spain. London: Routledge and Kegan Paul.

TORRES, C. I984. "Uma cultura velha da serra," in Mantas traditionais do Baixo Alentejo. Edited by A. Luzia, I. Magalhaes, and C. Torres. Mértola: Campo Arqueológico de Mértola.

\section{Meat Eating and Hominid Evolution ${ }^{1}$}

\author{
CRAIG B. STANFORD AND HENRY T. BUNN \\ Department of Anthropology, University of Southern \\ California, Los Angeles, Calif. 90089, U.S.A. \\ (stanford@almaak.usc.edu)/Department of \\ Anthropology, University of Wisconsin, Madison, Wis. \\ 53706-I395, U.S.A. (htbunn@facstaff.wisc.edu). \\ 30 XI 98
}

The role of hunting and scavenging in human evolution has been a subject of intense anthropological interest for decades and has produced some of the most widely discussed and debated research findings and interpretations in the history of the discipline. In spite of the central place assigned to studies of meat eating, scholars from the different subfields of biological anthropology rarely find themselves in the same room at traditional conference venues, and therefore research data from one subfield rarely penetrate the others. To remedy this and to discuss recent findings, a conference, "The Early Human Diet: The Role of Meat," was held October 2-5, I998, on the campus of the University of Wisconsin, Madison. The conference was sponsored by the Wenner-Gren Foundation for Anthropological Research and was organized by Craig B. Stanford (University of Southern California) and Henry T. Bunn (University of Wisconsin, Madison). The I 8 participants were paleoanthropologists, primatologists, archaeologists, and students of foragers and of carnivores, including some researchers whose fieldwork and expertise overlapped two or more of these specialities ${ }^{2}$. They had been chosen for their

I. (C) 1999 by The Wenner-Gren Foundation for Anthropological Research. All rights reserved o0 I I-3204/99/4005-0009\$I.00.

2. The conference participants, their affiliations, and paper titles were as follows: Michael Alvard, State University of New York at Buffalo, "Mutualistic Hunting"; Henry Bunn, University of Wisconsin, Madison, "The Role of Meat in Hadza Diet and Society: Archaeological Signatures and Evolutionary Implications"; Robert Foley, University of Cambridge, "The Evolutionary Consequences of Increased Carnivory in Hominids"; Kristen Hawkes, University of Utah, "Is Meat the Hunter's Property? Ownership and Explanations of Hunting and Sharing"; William McGrew, Miami University, "The Other Faunivory: Primate Insectivory and Early Human Diet"; Katharine Milton, University of California, Berkeley, "A Hypothesis to Explain the Role of Meat-eating in Human Evolution: A Means of Painting One's Way Out of an Evolutionary Corner"; Travis Pickering, University of Wisconsin, Madison, and University of the Witwatersrand, "Taphonomy of the Swartkrans Hominid Postcrania and Its Bearing on Issues of Fire Management, Meat-eating, and Extinction"; John Rick, Stanford University, "Specialized Meat-eating in the Holocene: An Archaeological Case from the Frigid Tropics of High-Altitude Peru"; Lisa Rose, Washington University, "Meat and the Early Human Diet: Insights from Neotropical Primate Studies"; Margaret Schoeninger, University of Wisconsin, Madison, "The Third Chimpanzee or the Fourth Ape: A Diet Perspective" (coauthored by Henry Bunn, Shawn Murray, and Travis Pickering); Jeanne Sept, Indiana University, "Modeling the Edible Landscape"; John Speth, University of Michigan, "Neanderthal Hunting and Meat-processing in the Near East: Evidence from 